\title{
Anthocyanin-rich blackcurrant extract inhibits proliferation of the MCF10A healthy human breast epithelial cell line through induction of G0/G1 arrest and apoptosis
}

\author{
NAOKI NANASHIMA ${ }^{1}$, KAYO HORIE ${ }^{1}$, MITSURU CHIBA ${ }^{1}$, \\ MANABU NAKANO $^{1}$, HAYATO MAEDA ${ }^{2}$ and TOSHIYA NAKAMURA ${ }^{1}$ \\ ${ }^{1}$ Department of Biomedical Sciences, Hirosaki University Graduate School of Health Sciences, Hirosaki, Aomori 036-8564; \\ ${ }^{2}$ Faculty of Agriculture and Life Science, Hirosaki University, Hirosaki, Aomori 036-8561, Japan
}

Received October 6, 2016; Accepted May 15, 2017

DOI: $10.3892 / \mathrm{mmr} .2017 .7391$

\begin{abstract}
Blackcurrants (Ribes nigrum L., Grossulariaceae) possess a high content of anthocyanin polyphenols, which have been demonstrated to exhibit beneficial effects on health due to their antioxidant and anticarcinogenic properties. The present study investigated novel functions of anthocyanin-rich blackcurrant extracts (BCEs) in a healthy mammary epithelial cell line, MCF10A. The percentages of viable cells were $85,75,53$ and $31 \%$ following exposure to 50 , 100,200 and $400 \mu \mathrm{g} / \mathrm{ml} \mathrm{BCE}$, respectively. The half-maximal response concentration of BCE was $237.7 \mu \mathrm{g} / \mathrm{ml}$. Microarray and Ingenuity ${ }^{\circledR}$ Pathway Analysis demonstrated that BCE downregulated cell cycle signaling, including upstream genes with mitotic roles such as polo-like kinase signaling. $\mathrm{BCE}$ increased the number of cells in the G0/G1 phase and decreased the number of cells in the $\mathrm{S}$ and $\mathrm{G} 2 / \mathrm{M}$ phases. Alkaline comet assays demonstrated that 50 and $100 \mu \mathrm{g} / \mathrm{ml}$ BCE induced DNA damage in a dose-dependent manner. Cultures treated with 0,50 , and $100 \mu \mathrm{g} / \mathrm{ml}$ BCE contained 4.6, 13.4 and $16.0 \%$ apoptotic cells, respectively. As compared with the untreated cultures $(1.9 \%)$, the number of necrotic cells increased in the $100 \mu \mathrm{g} / \mathrm{ml} \mathrm{BCE-treated} \mathrm{cultures} \mathrm{(from} 1.9$ to $4.3 \%$ ) but not in the $50 \mu \mathrm{g} / \mathrm{ml} \mathrm{BCE}$-treated cultures. Reverse transcription-quantitative polymerase chain reaction analysis demonstrated that $\mathrm{BCE}$ reduced mRNA expression of the genomic caretaker lysine-specific demethylas 5B (KDM5B).
\end{abstract}

Correspondence to: Dr Naoki Nanashima, Department of Biomedical Sciences, Hirosaki University Graduate School of Health Sciences, 66-1 Hon, Hirosaki, Aomori 036-8564, Japan E-mail: nnaoki@hirosaki-u.ac.jp

Abbreviations: AURKA, aurora kinase A; BCE, blackcurrant extract; KDM5B, lysine-specific demethylase 5B; RT-qPCR, reverse transcription-quantitative polymerase chain reaction

Key words: apoptosis, aurora kinase A, blackcurrant, DNA damage, lysine-specific demethylase $5 \mathrm{~B}$
The results suggested that blackcurrant anthocyanins may act as cell arrest and death inducers via KDM5B downregulation in healthy breast cells.

\section{Introduction}

Blackcurrants (Ribes nigrum L., Grossulariaceae) contain a number of biochemical constituents, including polyphenols, polyunsaturated fatty acids, organic acids and phenolic acids (1-4). Blackcurrant flavonoids are a group of polyphenolic compounds that include anthocyanins and flavonols. Anthocyanins are natural plant pigments that are widely distributed among flowers, fruits and vegetables. Blackcurrants are reported to contain four anthocyanins: Delphinidin-3-glucoside; delphinidin-3-rutinoside; cyanidin-3-glucoside; and cyanidin-3-rutinoside. Delphinidin-3-rutinoside and cyanidin-3-rutinoside are specific blackcurrant anthocyanins (2). These blackcurrant constituents have been associated with certain health benefits, including improved blood flow (5), decreased inflammatory marker levels (6) and protection against DNA damage induced by hydrogen peroxide (7).

Previous studies have demonstrated that blackcurrant phytochemicals exhibit anti-breast cancer effects. For example, blackcurrant extract (BCE) or juice has been demonstrated to inhibit breast cancer cell proliferation (8-10). However, the effects of BCEs on normal human breast epithelial cells have not been reported.

The objective of the present study was to investigate whether an anthocyanin-rich BCE confers novel health benefits to healthy breast epithelial cells. MCF10A healthy human breast epithelial cells were exposed to BCE, and microarray and Ingenuity ${ }^{\circledR}$ Pathway Analysis was performed to assess alterations in gene expression. The regulation of the cell cycle and the impact on cell viability was evaluated using fluorescence-activated cell sorting. DNA damage and cell death was examined by detecting apoptotic and necrotic cells using a comet assay. mRNA expression of the DNA stability regulator lysine-specific demethylase 5B (KDM5B) $(11,12)$ was investigated using the reverse transcription-quantitative polymerase chain reaction (RT-qPCR). 


\section{Materials and methods}

Materials and cell culture. The BCE powder, CaNZac-35, was purchased from Koyo Mercantile Co., Ltd. (Tokyo, Japan). The BCR powder contained high concentrations of polyphenols (37.6 g polyphenol/100 $\mathrm{g} \mathrm{BCE}$ ) and anthocyanins (38.0 g anthocyacin/100 g BCE) (13). MCF10A breast cancer cells were obtained from the American Type Culture Collection (Manassas, VA, USA). Cells were maintained in a Mammary Epithelial Cell Growth Medium kit (PromoCell $\mathrm{GmbH}$, Heidelberg, Germany). The culture experiments were conducted at $37^{\circ} \mathrm{C}$ in a humidified $5 \% \mathrm{CO}_{2}$ incubator.

Cell viability assay. MCF10A cells were seeded in 96-well plates at 5,000 cells/well and cultured overnight. Cells were then incubated with $0,10,25,50,100,200$ and $400 \mu \mathrm{g} / \mathrm{ml} \mathrm{BCE}$ for $24 \mathrm{~h}$, and observed under a fluorescence microscope at x200 magnification (FSX100; Olympus Corporation, Tokyo, Japan). Cell viability was determined using the PrestoBlue cell viability reagent (Invitrogen; Thermo Fisher Scientific, Inc., Waltham, MA, USA), according to the manufacturer's protocol. PrestoBlue reagent was added to the cells and cells were incubated for $6 \mathrm{~h}$ at $37^{\circ} \mathrm{C}$. Absorbance was measured on a Benchmark microplate reader (Bio-Rad Laboratories, Inc., Hercules, CA, USA) at a wavelength of $570 \mathrm{~nm}$. The absorbance was assumed to be directly proportional to the number of cells. BCE concentration-cell growth (dose effect) curves were drawn for each treatment and approximate half-maximal response concentration $\left(\mathrm{EC}_{50}\right)$ values were determined using Excel software (version 2013; Microsoft Corporation, Redmond, WA, USA).

Microarray gene expression profiling. MCF10A cells were seeded in $21-\mathrm{cm}^{2}$ culture dishes in mammary epithelial cell growth medium and grown under the conditions described above until confluent, at which point the medium was replaced with fresh medium with or without BCE $(50 \mu \mathrm{g} / \mathrm{m})$. After $24 \mathrm{~h}$ incubation, the cells were washed twice with PBS and total RNA was extracted using the RNeasy mini kit (Qiagen, Inc., Valencia, CA, USA). Total RNA (100 ng) was used to produce cyanine 3-CTP-labeled cRNA using a low input quick amp labeling kit (Agilent Technologies, Inc., Santa Clara, CA, USA). Labeled and fragmented cRNA was hybridized to a SurePrint G3 Human Gene Expression microarray (8x60K; version 2; Agilent Technologies, Inc.). Labeling, hybridization, image scanning and data analysis was performed at Bio Matrix Research, Inc. (Chiba, Japan). The MCF10A microarray dataset is available at www.ncbi.nlm.nih.gov/geo under accession code GSE58304.

Genes with $\geq 2$-fold upregulation following exposure of MCF10A cells to $50 \mu \mathrm{g} / \mathrm{ml} \mathrm{BCE}$ were analyzed using Ingenuity ${ }^{\circledR}$ Pathway Analysis software (version 18030641; Qiagen, Inc.).

Cell cycle analysis. Cell cycle analysis was performed as previously described $(13,14)$. MCF10A cells were seeded in $21-\mathrm{cm}^{2}$ culture dishes at $5 \times 10^{5}$ cells/well and cultured overnight. The medium was then replaced with fresh medium with or without $\mathrm{BCE}(0,50$ or $100 \mu \mathrm{g} / \mathrm{ml})$. The cells were cultured for $24 \mathrm{~h}$ prior to DNA staining with propidium iodide at room temperature for $2 \mathrm{~h}$. Cell cycle analysis was performed by fluorescence-activated cell sorting, which was conducted using a Cell Cycle Phase Determination kit (Cayman Chemical Company, Ann Arbor, MI, USA) and a Cytomics FC500 flow cytometer (Beckman Coulter, Inc., Brea, CA, USA). Data were analyzed using CXP analysis software (version 2.0; Beckman Coulter, Inc.).

Alkali comet assay. A Trevigen Comet Assay ${ }^{\mathrm{TM}}$ kit (Trevigen, Gaithersburg, MD, USA) was used to assess DNA strand breaks. MCF10A cells were treated with $\mathrm{BCE}$ or $\mathrm{H}_{2} \mathrm{O}_{2}$ as a positive control for $24 \mathrm{~h}$ and resuspended in ice-cold PBS at a density of $1 \times 10^{5}$ cells $/ \mathrm{ml}$. A $50-\mu 1$ aliquot of cell suspension (containing $1 \times 10^{5}$ cells $/ \mathrm{ml}$ ) was mixed with $500 \mu 11 \%$ low-melting agarose maintained at $37^{\circ} \mathrm{C}$. A total $50 \mu \mathrm{l}$ mixture was immediately obtained and evenly spread onto the comet slides. To accelerate gelling of the agarose disc, the slides were incubated at $4^{\circ} \mathrm{C}$ in the dark for $10 \mathrm{~min}$. The slides were subsequently transferred to a prechilled lysis solution and incubated for $60 \mathrm{~min}$ at $4^{\circ} \mathrm{C}$. The slides were then transferred to an alkali unwinding solution [200 mM NaOH, 1 mM EDTA (pH>13.0)] and incubated at room temperature for $20 \mathrm{~min}$ in the dark to perform denaturation. Subsequently, the slides were transferred to a prechilled alkaline electrophoresis solution and electrophoresed at $21 \mathrm{~V}$ for $30 \mathrm{~min}$ followed by washing with distilled water. The slides were then immersed in ice-cold $70 \%$ ethanol at room temperature for $5 \mathrm{~min}$ and air-dried. The slides were incubated with $100 \mu 1$ SYBR Green I dye [Thermo Fisher Scientific, Inc.; in $10 \mathrm{mM}$ Tris- $\mathrm{HCl}$ (pH 7.5), $1 \mathrm{mM}$ EDTA buffer] for $5 \mathrm{~min}$ at $4^{\circ} \mathrm{C}$ to stain the DNA and were immediately analyzed using an FSX100 fluorescence microscope. The images were captured at X100 magnification. Quantitative analysis of tail length was performed using the Comet Assay IV image analysis system (Perceptive Instruments Ltd., Bury St Edmunds, UK).

Cell death detection. MCF10A cells were seeded in $9-\mathrm{cm}^{2}$ culture dishes and cultured overnight. The medium was then replaced with fresh medium with or without $\mathrm{BCE}(0,50$ or $100 \mu \mathrm{g} / \mathrm{ml}$ ). Apoptosis and necrosis was detected using a Cell Meter $^{\mathrm{TM}}$ Apoptotic and Necrotic Detection kit (AAT Bioquest, Inc., Sunnyvale, CA, USA). The cells were observed with an FSX100 fluorescence microscope. The images were captured at X42 magnification. Quantitative analysis of apoptotic and necrotic cells was performed using FSX-BSW software (version 03.01; Olympus Corporation).

$R T-q P C R$. MCF10A cells were seeded in 9- $\mathrm{cm}^{2}$ culture dishes and cultured as described above until confluent. The used medium was then replaced with fresh medium with or without $\operatorname{BCE}(0,25$ or $50 \mu \mathrm{g} / \mathrm{ml})$. The cells were incubated for $24 \mathrm{~h}$ and washed twice with PBS. Total RNA was extracted using the RNeasy mini kit (Qiagen, Inc.). cDNA was reverse-transcribed from total RNA $(0.5 \mu \mathrm{g})$ using the Omniscript RT kit (Qiagen, Inc.). A MiniOpticon Real-Time PCR system (Bio-Rad Laboratories, Hercules, CA, USA) and GoTaq Green Master Mix (Promega Corporation, Madison, WI, USA) were used for the quantification of specific mRNA. PCRs were denatured at $92^{\circ} \mathrm{C}$ for $2 \mathrm{~min}$, and amplified at $92^{\circ} \mathrm{C}$ for $30 \mathrm{sec}, 58^{\circ} \mathrm{C}$ for $30 \mathrm{sec}$ and $72^{\circ} \mathrm{C}$ for $30 \mathrm{sec}$, for 40 cycles. Transcript levels were normalized to that of GAPDH cDNA. The primers used 


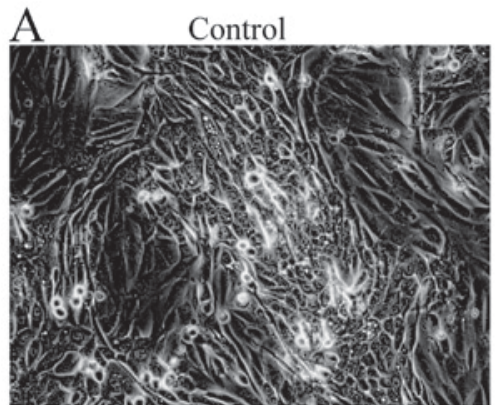

$\operatorname{BCE} 100(\mu \mathrm{g} / \mathrm{ml})$
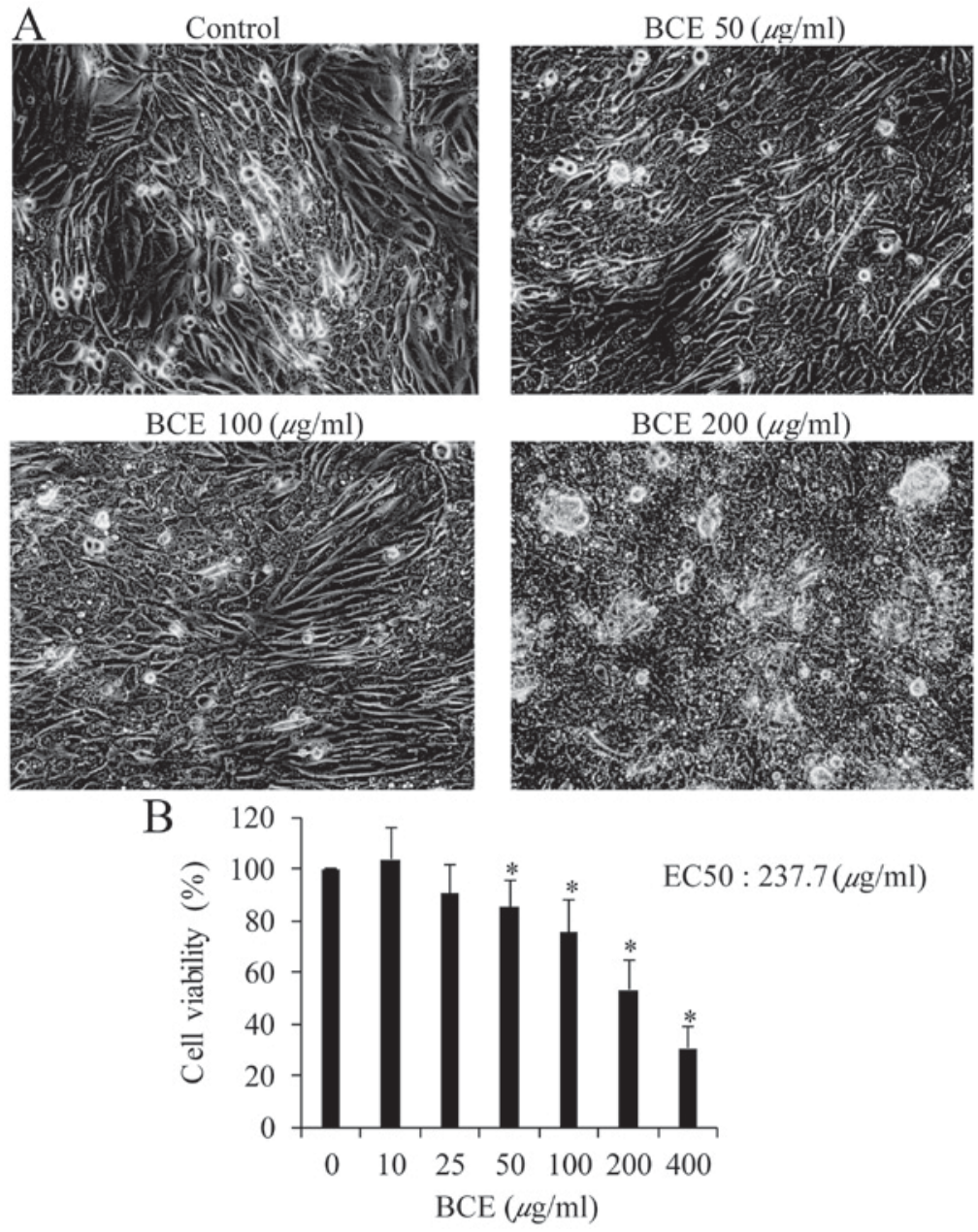

BCE $200(\mu \mathrm{g} / \mathrm{ml})$

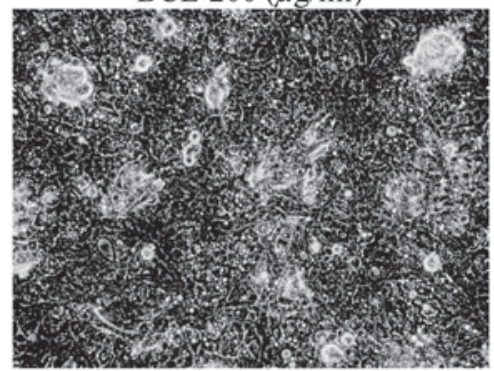

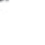




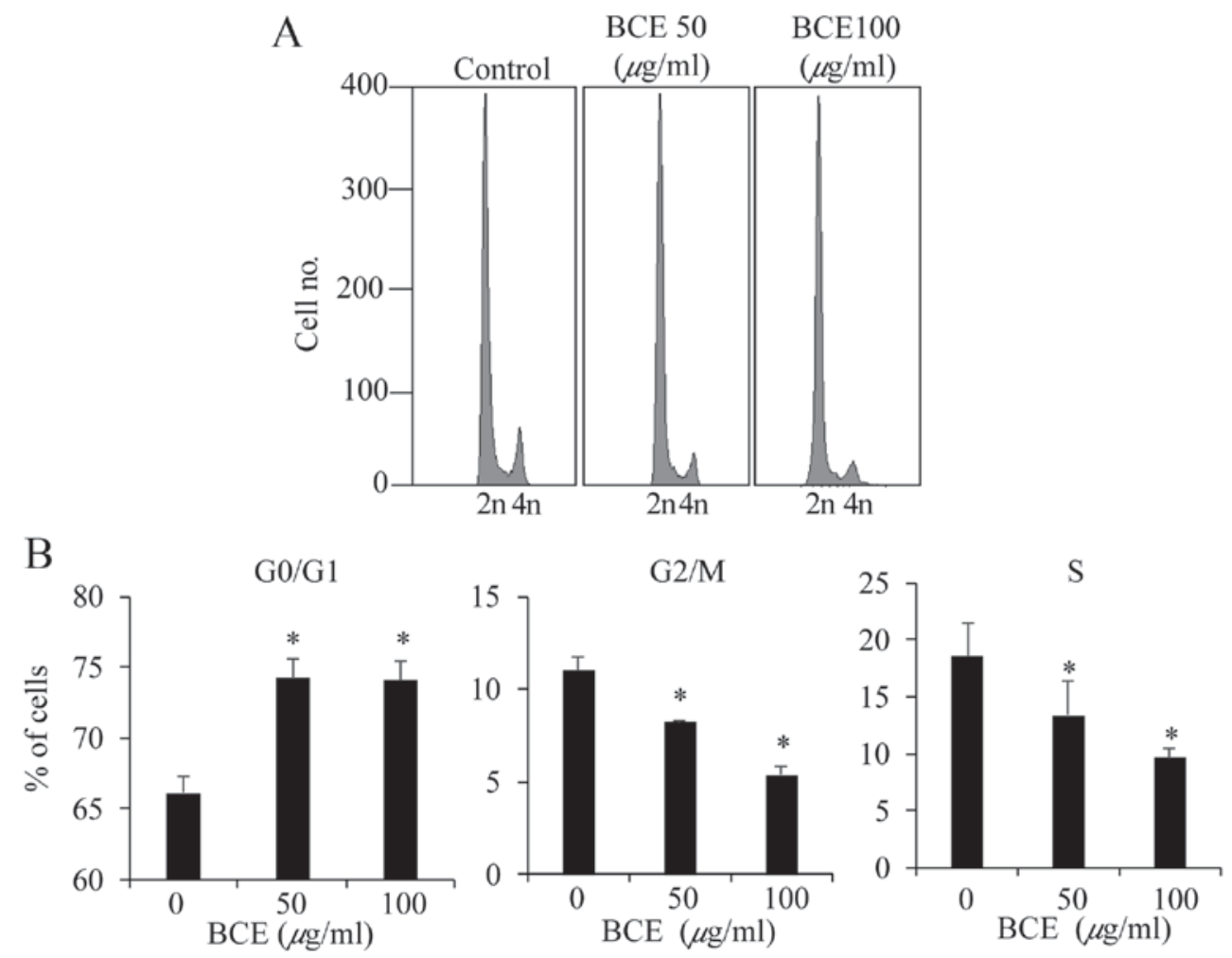

Figure 3. Cell cycle analysis in MCF10A cells treated with BCE for $24 \mathrm{~h}$ prior to DNA staining and fluorescence-activated cell sorting. (A) Cell cycle plots. (B) The percentages of cells in the G0/G1, G2/M and S phases. Data were analyzed using MultiCycle AV software and represent the mean \pm standard error of the mean from three independent experiments. ${ }^{*} \mathrm{P}<0.01$ vs. the untreated control cells. BCE, blackcurrant extract.

respectively (Fig. 1B). There was no significant alteration in the viability of cells exposed to 10 or $25 \mu \mathrm{g} / \mathrm{ml} \mathrm{BCE}$.

Ingenuity Pathway Analysis. To investigate the impact of $\mathrm{BCE}$ on MCF10A cells, gene expression in the cells prior to and following BCE treatment was compared using microarrays. Ingenuity Pathway Analysis was used to investigate the functional associations between sets of genes with modified expression levels. Given that $50 \mu \mathrm{g} / \mathrm{ml}$ BCE did not affect MCF10A cell morphology and the $\mathrm{EC}_{50}$ value of $\mathrm{BCE}$ was $237.7 \mu \mathrm{g} / \mathrm{ml}$ (Fig. 1B), a concentration of $50 \mu \mathrm{g} / \mathrm{ml}$ was selected for microarray analysis. A total of 147 significant canonical pathways were identified $(\mathrm{P}<0.05)$, the majority of which were associated with cell cycle signaling functions. The primary canonical pathways were 'mitotic roles of polo-like kinase', 'G2/M DNA damage checkpoint regulation', 'the role of checkpoint kinase proteins in cell cycle', 'cell cycle control of chromosomal replication checkpoint control' and 'ataxia telangiectasia mutated signaling' (Fig. 2). Detailed gene expression alterations in each significantly affected canonical pathway are presented in Table I. Mitotic roles of polo-like kinase-related genes were affected the most. Certain genes were common genes altered between mitotic roles of polo-like kinase and other canonical pathways (G2/M DNA damage checkpoint regulation, role of checkpoint kinase proteins in cell cycle or ataxia telangiectasia mutated signaling) (Table I). These results indicate that BCE is associated with significantly downregulated expression levels of 'mitotic roles of Polo-like kinase' and 'cell cycle control of chromosomal replication checkpoint control' genes.
Cell cycle analysis. MCF10A cells were treated with BCE $(0,50$ and $100 \mu \mathrm{g} / \mathrm{ml})$ for $24 \mathrm{~h}$ prior to cell cycle analysis. Treatment with BCE significantly increased the proportion of G0/G1 phase cells, and decreased the proportions of G2/M phase and $\mathrm{S}$ phase cells (Fig. 3). These results indicate that BCE inhibits cell cycle progression by inducing G0/G1 arrest in MCF10A cells.

BCE-induced DNA damage. As DNA damage is an early event of cell cycle arrest, it was further examined whether BCE induces DNA damage in MCF10A cells. As presented in Fig. 4A and B, 50 and $100 \mu \mathrm{g} / \mathrm{ml} \mathrm{BCE}$ induced DNA damage in a dose-dependent manner as measured by alkaline comet assay. The comet tail lengths of $0,50,100 \mu \mathrm{g} / \mathrm{ml} \mathrm{BCE-} \mathrm{and}$ $\mathrm{H}_{2} \mathrm{O}_{2}$-treated MCF10A cells were $11.4,15.9,22.9$, and $41.6 \mu \mathrm{m}$, respectively. These results suggest that $\mathrm{BCE}$ caused significant DNA damage.

Induction of apoptosis and necrosis. As BCE decreased cell viability and induced G0/G1 phase arrest and DNA damage in MCF10A, it was hypothesized that BCE may contribute to cell death. To examine this possibility, the number of apoptotic and necrotic MCF10A cells were counted following treatment with BCE. The cultures treated with 0,50 and $100 \mu \mathrm{g} / \mathrm{ml}$ BCE contained 4.6, 13.4 and 16.0\% apoptotic cells, respectively (Fig. 4C and D). As compared with the untreated cells (1.9\%), the percentage of necrotic cells increased in the $100 \mu \mathrm{g} / \mathrm{ml} \mathrm{BCE}$-treated culture (4.3\%) but not in the $50 \mu \mathrm{g} / \mathrm{ml}$ BCE-treated culture (Fig. 4C and D). These results indicate that $\mathrm{BCE}$ acts as an apoptotic inducer in MCF10A cells. 
Table I. Details of altered gene expression in canonical pathways.

\begin{tabular}{|c|c|c|c|}
\hline Canonical pathway & Gene symbol & Gene name & Fold-change \\
\hline \multirow{16}{*}{$\begin{array}{l}\text { Mitotic roles of polo-like kinase } \\
\text { related genes }\end{array}$} & AURKA & Aurora kinase A & 0.46 \\
\hline & CCNB1 & Cyclin B 1 & 0.40 \\
\hline & $\mathrm{CCNB} 2$ & Cyclin B2 & 0.37 \\
\hline & CDC20 & Cell division cycle 20 & 0.37 \\
\hline & CDC25A & Cell division cycle $25 \mathrm{~A}$ & 0.44 \\
\hline & CDC25C & Cell division cycle $25 \mathrm{C}$ & 0.44 \\
\hline & CDK1 & Cyclin-dependent kinase 1 & 0.43 \\
\hline & CHEK2 & Checkpoint kinase 2 & 0.48 \\
\hline & ESPL1 & Extra spindle pole bodies homolog 1 & 0.45 \\
\hline & FBXO5 & F-box protein 5 & 0.43 \\
\hline & KIF11 & Kinesin family member 11 & 0.48 \\
\hline & KIF23 & Kinesin family member 23 & 0.41 \\
\hline & PKMYT1 & Protein kinase, membrane associated tyrosine/threonine 1 & 0.42 \\
\hline & PLK1 & Polo-like kinase 1 & 0.42 \\
\hline & PLK4 & Polo-like kinase 4 & 0.41 \\
\hline & PRC1 & Protein regulator of cytokinesis 1 & 0.39 \\
\hline \multirow{9}{*}{$\begin{array}{l}\text { Cell cycle: G2/M DNA damage } \\
\text { checkpoint regulation }\end{array}$} & CCNB1 & Cyclin B1 & 0.40 \\
\hline & CCNB2 & Cyclin B2 & 0.37 \\
\hline & $\mathrm{CDC} 25 \mathrm{C}$ & Cell division cycle $25 \mathrm{C}$ & 0.44 \\
\hline & CDK1 & Cyclin-dependent kinase 1 & 0.43 \\
\hline & CHEK2 & Checkpoint kinase 2 & 0.48 \\
\hline & CKS2 & CDC28 protein kinase regulatory subunit 2 & 0.49 \\
\hline & PKMYT1 & Protein kinase, membrane associated 1 tyrosine/threonine & 0.42 \\
\hline & PLK1 & Polo-like kinase 1 & 0.42 \\
\hline & TOP2A & Topoisomerase (DNA) II $\alpha$ & 0.46 \\
\hline \multirow{8}{*}{$\begin{array}{l}\text { Role of CHK proteins in cell cycle } \\
\text { checkpoint control }\end{array}$} & CDC25A & Cell division cycle $25 \mathrm{~A}$ & 0.44 \\
\hline & $\mathrm{CDC} 25 \mathrm{C}$ & Cell division cycle $25 \mathrm{C}$ & 0.44 \\
\hline & CDK1 & Cyclin-dependent kinase 1 & 0.43 \\
\hline & CHEK2 & Checkpoint kinase 2 & 0.48 \\
\hline & CLSPN & Claspin & 0.50 \\
\hline & PLK1 & Polo-like kinase 1 & 0.42 \\
\hline & RFC3 & Replication factor $\mathrm{C}$ subunit 3 & 0.37 \\
\hline & SLC19A1 & Solute carrier family 19 (folate transporter), member 1 & 0.48 \\
\hline \multirow{6}{*}{$\begin{array}{l}\text { Cell cycle control of chromosomal } \\
\text { replication }\end{array}$} & CDC45 & Cell division cycle 45 & 0.38 \\
\hline & CDT1 & Chromatin licensing and DNA replication factor 1 & 0.43 \\
\hline & CHEK2 & Checkpoint kinase 2 & 0.48 \\
\hline & MCM7 & Minichromosome maintenance complex component 7 & 0.48 \\
\hline & ORC1 & Origin recognition complex subunit 1 & 0.31 \\
\hline & ORC6 & Origin recognition complex subunit 6 & 0.37 \\
\hline \multirow{9}{*}{$\begin{array}{l}\text { Ataxia telangiectasia mutated } \\
\text { signaling }\end{array}$} & BLM & Bloom syndrome, recQ helicase-like & 0.44 \\
\hline & CCNB1 & Cyclin B1 & 0.40 \\
\hline & CCNB2 & Cyclin B2 & 0.37 \\
\hline & $\mathrm{CDC} 25 \mathrm{~A}$ & Cell division cycle $25 \mathrm{~A}$ & 0.44 \\
\hline & $\mathrm{CDC} 25 \mathrm{C}$ & Cell division cycle $25 \mathrm{C}$ & 0.44 \\
\hline & CDK1 & Cyclin-dependent kinase 1 & 0.43 \\
\hline & CHEK2 & Checkpoint kinase 2 & 0.48 \\
\hline & RAD51 & RAD51 recombinase & 0.50 \\
\hline & TP73 & Tumor protein p73 & 15.20 \\
\hline
\end{tabular}

$B C E$ decreases KDM5B expression. As KDM5B is known to be a DNA stability regulator with high expression in breast cancer cells, its gene expression was investigated by RT-qPCR. Treatment with BCE decreased KDM5B expression in a 

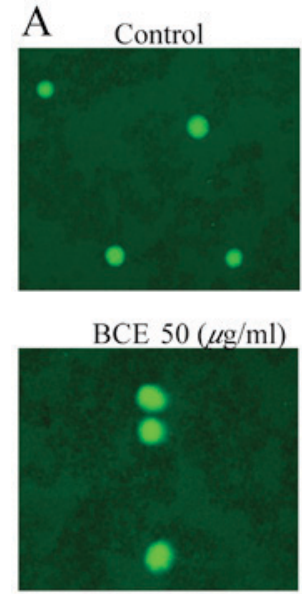

C

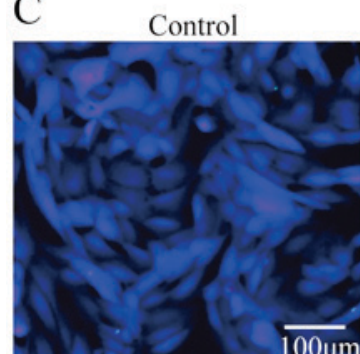

$\mathrm{H}_{2} \mathrm{O}_{2}$

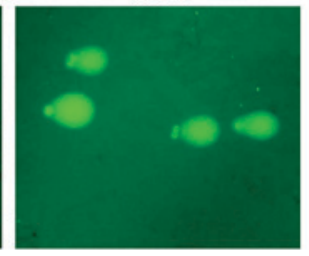

$\mathrm{BCE} 100(\mu \mathrm{g} / \mathrm{ml})$
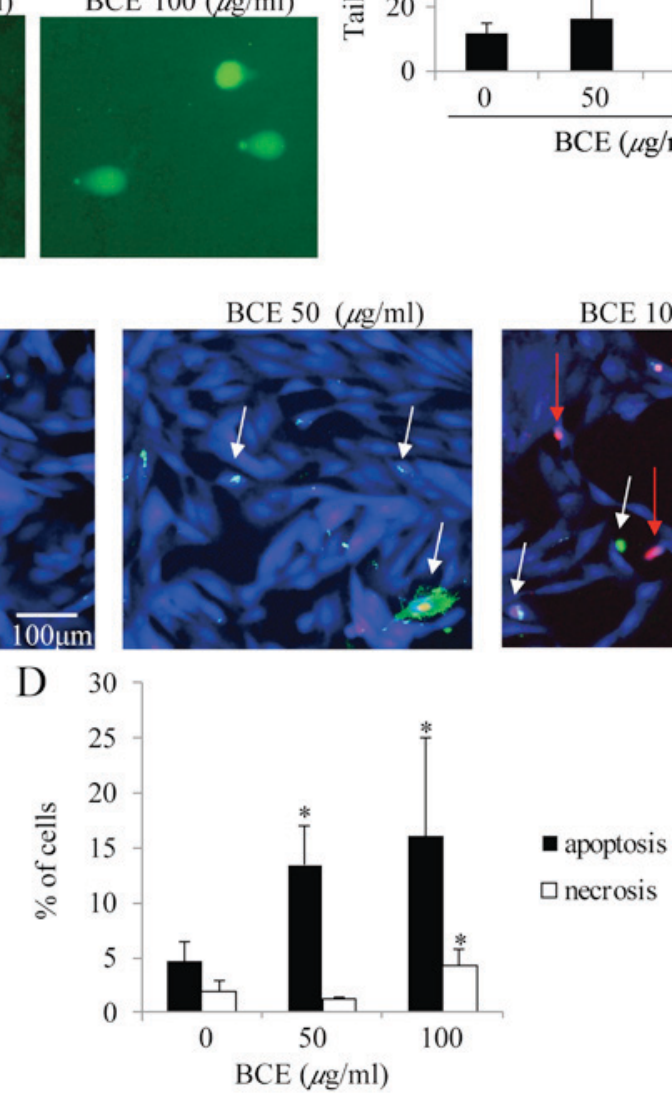

$\operatorname{BCE} 100(\mu \mathrm{g} / \mathrm{ml})$

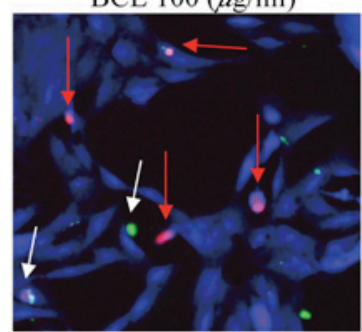

$\cdot$

Figure 4. Analysis of DNA damage and cell death in breast epithelial cells treated with BCE. (A) Images of cells treated with $\mathrm{BCE}$ for $24 \mathrm{~h}$ (with $100 \mu \mathrm{M} \mathrm{H}_{2} \mathrm{O}_{2}$ as positive control). DNA damage was determined using an alkaline comet assay. (B) Quantitative analysis of tail length by Comet Assay IV software. Tail length indicates DNA damage. (C) Images of apoptotic cells (white arrows) and necrotic cells (red arrows). Scale bar, $100 \mu \mathrm{m}$. (D) Percentage of apoptotic and necrotic cells in MCF10A cells treated with BCE. Data represent the mean \pm standard error of the mean from at least three independent experiments. ${ }^{*} \mathrm{P}<0.01$ vs. the untreated control cells. BCE, blackcurrant extract.

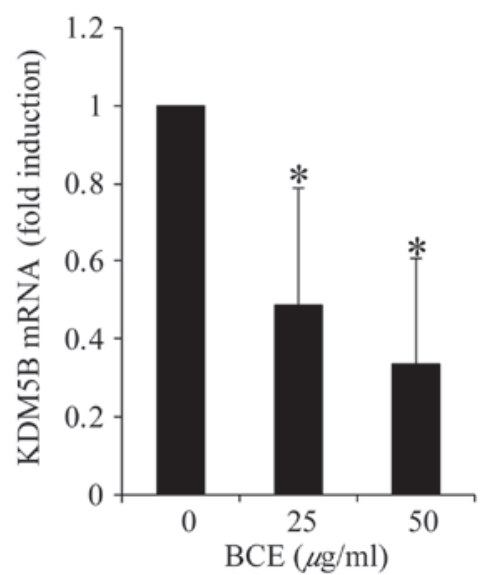

Figure 5. Effect of BCE on the mRNA levels of KDM5B. MCF10A cells were treated with BCE for $24 \mathrm{~h}$. mRNA levels of KDM5B were measured using the reverse transcription-quantitative polymerase chain reaction. Data represent the mean \pm standard error of the mean from at least three independent experiments. " $\mathrm{P}<0.01$ vs. the untreated control cells. BCE, blackcurrant extract; KDM5B, lysine-specific demethylase 5B. dose-dependent manner (Fig. 5). These result indicate that BCE induces KDM5B downregulation.

\section{Discussion}

In addition to the known health benefits of blackcurrants, the present study investigated a novel function of anthocyanin-rich BCE in the MCF10A healthy mammary epithelial cell line. The present study demonstrated that exposure of MCF10A cells to $\mathrm{BCE}$ reduces the expression of genes involved in cell signaling pathways, including the mitotic roles of polo-like kinase signaling and associated genes, and induces G0/G1 arrest and cell death. Although canonical pathway analysis demonstrated that $\mathrm{BCE}$ reduced certain signaling pathways, certain genes were common among pathways. The important dysregulated signaling pathways appeared to be the 'mitotic roles of polo-like kinase' and 'cell cycle control of chromosomal replication checkpoint control' pathways. Fluorescence-activated cell sorting analysis revealed that cell cycle arrest reduced $\mathbf{M}$ 
and $\mathrm{S}$ phase cells, and the comet assay revealed DNA damage following exposure to 50 or $100 \mu \mathrm{g} / \mathrm{ml} \mathrm{BCE}$. Previous studies have demonstrated that polyphenols induce DNA damage, and G2/M or G0/G1 cell cycle arrest (16-19).

$\mathrm{BCE}$ has been demonstrated to exert an anti-proliferative effect on HT29 colon cancer cells, possibly through the suppression of the cyclin-dependent kinase inhibitor 1 (p21 ${ }^{\mathrm{WAFl}}$ ) signaling pathway (20) and a potent cytotoxic effect against hepatocellular carcinoma (21). However, in the present study, microarray and Ingenuity Pathway Analysis did not indicate suppression of the $\mathrm{p} 21^{\mathrm{WAF} 1}$ signaling pathway (data not shown).

Microarray and Ingenuity Pathway Analysis revealed a reduction in polo-like kinase signaling and associated genes. It is known that almost every step of cell division, from entry into mitosis to cytokinesis, is regulated by protein phosphorylation by certain kinases, including aurora kinase A (AURKA), AURKB, the cyclin-dependent kinase/cyclin B complex and polo-kinase 1 (PLK1) $(22,23)$. As the AURKs are frequently overexpressed in cancer cells, it is hypothesized that AURKA may cause the progression of gene instability observed in cancer. Furthermore, AURKA and PLK1 cross-talk during mitotic entry and spindle assembly (24). Therefore, inhibitors of AURK activity may have the potential to be used as novel anticancer agents. As BCE suppressed AURKA and PLK1 expression, the present study may lead to the development of a treatment for the prevention of breast cancer.

Phytoestrogens are chemical compounds synthesized by plants and are obtained naturally in a wide range of foods, and can have estrogenic effects (25-28). The authors previously reported that low-density blackcurrant anthocyanins and BCE exhibit phytoestrogenic activity mediated via estrogen receptor $\alpha$ signaling (13). As certain phytoestrogens were demonstrated to inhibit breast cell proliferation and induce apoptosis $(29,30)$, it was hypothesized that BCE may be effective for the prevention of the breast cancer. Anthocyanins or polyphenols cause DNA damage and are known to cause apoptosis, by activation of the ataxia telangiectasia-mutated signaling gene and induction of p53 and p21 (31-33). However, in the present study, ataxia telangiectasia-mutated signaling was not activated and expression of the key regulator of DNA stability, KDM5B, was decreased. These results are different from previous reports.

KDM5B with methylation $\mathrm{H} 3 \mathrm{~K} 4$ is required for mammary gland development and serves an important role in the proliferative capacity of breast cancer cells $(34,35)$. The interaction of cyclin B1 and cyclin-dependent kinase 1 is essential for control of the cell cycle at the G2/M phase. Conversely, KDM5B has been reported to possibly be involved in the regulation of the G2/M checkpoint and late $M$ phase of the cell cycle (36-39). Furthermore, interference of KDM5B was demonstrated to increase the accumulation of G1 phase MCF7 breast cancer cells (40). As treatment with $\mathrm{BCE}$ reduces KDM5B expression, and induces DNA damage, G0/G1 cell cycle arrest and apoptosis in MCF10A cells, $\mathrm{BCE}$ may prove to be useful as a breast cancer preventative food.

In conclusion, the present study demonstrated that anthocyanin-rich BCE induces G0/G1 cell cycle arrest and apoptosis in the normal breast epithelial cell line MCF10A. $\mathrm{BCE}$ dysregulated polo-like kinase signaling and reduced breast cancer cell proliferation-associated genes, including AURKA and KDM5B. These results suggest that blackcurrant anthocyanins may be useful as a component of breast cancer prevention.

\section{Acknowledgements}

The authors of the present study would like to thank Ms. Yukimi Kato (Hirosaki University, Hirosaki, Japan) and Ms. Chiaki Uehara (Hirosaki University) for their support, and Editage (www.editage.jp) for their English language editing. The present study was supported in part by a Hirosaki University Institutional Research Grant for Young Scientists and a Grant-in-Aid from the Japan Cassis Association.

\section{References}

1. Delazar A, Khodaie L, Afshar J, Nahar L and Sarker SD: Isolation and free-radical-scavenging properties of cyanidin 3-O-glycosides from the fruits of Ribes biebersteinii. Berl. Acta Pharm 60: 1-11, 2010.

2. Gopalan A, Reuben SC, Ahmed S, Darvesh AS, Hohmann J and Bishayee A: The health benefits of blackcurrants. Food Funct 3: 795-809, 2012.

3. Määttä KR, Kamal-Eldin A and Törrönen AR: High-performance liquid chromatography (HPLC) analysis of phenolic compounds in berries with diode array and electrospray ionization mass spectrometric (MS) detection: Ribes species. J Agric Food Chem 51: 6736-6744, 2003.

4. Nielsen IL, Haren GR, Magnussen EL, Dragsted LO and Rasmussen SE: Quantification of anthocyanins in commercial black currant juices by simple high-performance liquid chromatography. Investigation of their $\mathrm{pH}$ stability and antioxidative potency. J Agric Food Chem 51: 5861-5866, 2003.

5. Matsumoto H, Takenami E, Iwasaki-Kurashige K, Osada T, Katsumura T and Hamaoka T: Effects of blackcurrant anthocyanin intake on peripheral muscle circulation during typing work in humans. Eur J Appl Physiol 94: 36-45, 2005.

6. Zhu Y, Xia M, Yang Y, Liu F, Li Z, Hao Y, Mi M, Jin T and Ling W: Purified anthocyanin supplementation improves endothelial function via NO-cGMP activation in hypercholesterolemic individuals. Clin Chem 57: 1524-1533, 2011.

7. Yamamoto A, Nakashima K, Kawamorita S, Sugiyama A, Miura M, Kamitai Y and Kato Y: Protective effects of raw and cooked blackcurrant extract on DNA damage induced by hydrogen peroxide in human lymphoblastoid cells. Pharm Biol 52: 782-788, 2014.

8. Aiyer HS, Warri AM, Woode DR, Hilakivi-Clarke L and Clarke R: Influence of berry polyphenols on receptor signaling and cell-death pathways: Implications for breast cancer prevention. J Agric Food Chem 60: 5693-5708, 2012.

9. Boivin D, Blanchette M, Barrette S, Moghrabi A and Beliveau R: Inhibition of cancer cell proliferation and suppression of TNF-induced activation of NFkappaB by edible berry juice. Anticancer Res 27: 937-948, 2007.

10. Olsson ME, Gustavsson KE, Andersson S, Nilsson A and Duan RD: Inhibition of cancer cell proliferation in vitro by fruit and berry extracts and correlations with antioxidant levels. J Agric Food Chem 52: 7264-7271, 2004.

11. Catchpole S, Spencer-Dene B, Hall D, Santangelo S, Rosewell I, Guenatri M, Beatson R, Scibetta AG, Burchell JM and Taylor-Papadimitriou J: PLU-1/JARID1B/KDM5B is required for embryonic survival and contributes to cell proliferation in the mammary gland and in ER+ breast cancer cells. Int J Oncol 38: 1267-1277, 2011.

12. Li X, Liu L, Yang S, Song N, Zhou X, Gao J, Yu N, Shan L, Wang Q, Liang J, et al: Histone demethylase KDM5B is a key regulator of genome stability. Proc Natl Acad Sci USA 111: 7096-7101, 2014.

13. Nanashima N, Horie K, Tomisawa T, Chiba M, Nakano M, Fujita T, Maeda H, Kitajima M, Takamagi S, Uchiyama D, et al: Phytoestrogenic activity of blackcurrant (Ribes nigrum) anthocyanins is mediated through estrogen receptor alpha. Mol Nutr Food Res 59: 2419-2431, 2015. 
14. Nanashima N, Yamada T, Shimizu T and Tsuchida S: Deletion of phospholipase A2 group IVc induces apoptosis in rat mammary tumour cells by the nuclear factor- $\kappa \mathrm{B} /$ lipocalin 2 pathway. Biochem J 469: 315-324, 2015.

15. Livak KJ and Schmittgen TD: Analysis of relative gene expression data using real-time quantitative PCR and the 2(-Delta Delta C(T)) method. Methods 25: 402-408, 2001.

16. Lin CJ, Chang YA, Lin YL, Liu SH, Chang CK and Chen RM: Preclinical effects of honokiol on treating glioblastoma multiforme via G1 phase arrest and cell apoptosis. Phytomedicine 23: 517-527, 2016.

17. Lu JJ, Cai YJ and Ding J: Curcumin induces DNA damage and caffeine-insensitive cell cycle arrest in colorectal carcinoma HCT116 cells. Mol Cell Biochem 354: 247-252, 2011.

18. Ouyang G, Yao L, Ruan K, Song G, Mao Y and Bao S: Genistein induces $\mathrm{G} 2 / \mathrm{M}$ cell cycle arrest and apoptosis of human ovarian cancer cells via activation of DNA damage checkpoint pathways. Cell Biol Int 33: 1237-1244, 2009.

19. Zhang Z, Wang CZ, Du GJ, Qi LW, Calway T, He TC, Du W and Yuan CS: Genistein induces G2/M cell cycle arrest and apoptosis via $\mathrm{ATM} / \mathrm{p} 53$-dependent pathway in human colon cancer cells. Int J Oncol 43: 289-296, 2013.

20. Wu QK, Koponen JM, Mykkanen HM and Törrönen AR: Berry phenolic extracts modulate the expression of p21 (WAF1) and Bax but not Bcl-2 in HT-29 colon cancer cells. J Agric Food Chem 55: 1156-1163, 2007.

21. Bishayee A, Haznagy-Radnai E, Mbimba T, Sipos P, Morazzoni P, Darvesh AS, Bhatia D and Hohmann J: Anthocyanin-rich black currant extract suppresses the growth of human hepatocellular carcinoma cells. Nat Prod Commun 5: 1613-1618, 2010.

22. Strebhardt K: Multifaceted polo-like kinases: Drug targets and antitargets for cancer therapy. Nat Rev Drug Discov 9: 643-660, 2010.

23. Weng Ng WT, Shin JS, Roberts TL, Wang B and Lee CS: Molecular interactions of polo-like kinase 1 in human cancers J Clin Pathol 69: 557-562, 2016.

24. Asteriti IA, De Mattia F and Guarguaglini G: Cross-talk between AURKA and Plk1 in mitotic entry and spindle assembly. Front Oncol 5: 283, 2015.

25. Guo D, Wang J, Wang X, Luo H, Zhang H, Cao D, Chen L and Huang N: Double directional adjusting estrogenic effect of naringin from Rhizoma drynariae (Gusuibu). J Ethnopharmacol 138 451-457, 2011.

26. Lee YM, Kim JB, Bae JH, Lee JS, Kim PS, Jang HH and Kim HR: Estrogen-like activity of aqueous extract from Agrimonia pilosa Ledeb. in MCF-7 cells. BMC Complement Altern Med 12: 260, 2012.

27. Limer JL and Speirs V: Phyto-oestrogens and breast cancer chemoprevention. Breast Cancer Res 6: 119-127, 2004.

28. Mahmoud AM, Yang W and Bosland MC: Soy isoflavones and prostate cancer: A review of molecular mechanisms. J Steroid Biochem Mol Biol 140: 116-132, 2014.

29. Li T, Zhu J, Guo L, Shi X, Liu Y and Yang X: Differential effects of polyphenols-enriched extracts from hawthorn fruit peels and fleshes on cell cycle and apoptosis in human MCF-7 breast carcinoma cells. Food Chem 141: 1008-1018, 2013.

30. Rice S and Whitehead SA: Phytoestrogens oestrogen synthesis and breast cancer. J Steroid Biochem Mol Biol 108: 186-195, 2008 .
31. Seo HS, Ju JH, Jang K and Shin I: Induction of apoptotic cell death by phytoestrogens by up-regulating the levels of phospho-p53 and p21 in normal and malignant estrogen receptor $\alpha$-negative breast cells. Nutr Res 31: 139-146, 2011.

32. Prasad R and Katiyar SK: Polyphenols from green tea inhibit the growth of melanoma cells through inhibition of class I histone deacetylases and induction of DNA damage. Genes Cancer 6: 49-61, 2015.

33. Demoulin B, Hermant M, Castrogiovanni C, Staudt C and Dumont P: Resveratrol induces DNA damage in colon cancer cells by poisoning topoisomerase II and activates the ATM kinase to trigger p53-dependent apoptosis. Toxicol In Vitro 29: $1156-1165,2015$.

34. Yamane K, Tateishi K, Klose RJ, Fang J, Fabrizio LA Erdjument-Bromage $\mathrm{H}$, Taylor-Papadimitriou J, Tempst $\mathrm{P}$ and Zhang Y: PLU-1 is an H3K4 demethylase involved in transcriptional repression and breast cancer cell proliferation. Mol Cell 25: 801-812, 2007.

35. Zou MR, Cao J, Liu Z, Huh SJ, Polyak K and Yan Q: Histone demethylase jumonji AT-rich interactive domain 1B (JARID1B) controls mammary gland development by regulating key developmental and lineage specification genes. J Biol Chem 289: $17620-17633,2014$

36. Barrett KL, Demiranda D and Katula KS: Cyclin b1 promoter activity and functional cdk1 complex formation in G1 phase of human breast cancer cells. Cell Biol Int 26: 19-28, 2002.

37. Chang DC, Xu N and Luo KQ: Degradation of cyclin B is required for the onset of anaphase in Mammalian cells. J Biol Chem 278: 37865-37873, 2003.

38. Ducommun B, Brambilla P, Félix MA, Franza BR Jr, Karsenti E and Draetta G: cdc2 phosphorylation is required for its interaction with cyclin. EMBO J 10: 3311-3319, 1991.

39. Scibetta AG, Santangelo S, Coleman J, Hall D, Chaplin T, Copier J, Catchpole S, Burchell J and Taylor-Papadimitriou J: Functional analysis of the transcription repressor PLU-1/JARID1B. Mol Cell Biol 27: 7220-7235, 2007.

40. Mitra D, Das PM, Huynh FC and Jones FE: Jumonji/ARID1 B (JARID1B) protein promotes breast tumor cell cycle progression through epigenetic repression of microRNA let-7e. J Biol Chem 286: 40531-40535, 2011 